\title{
Total quality management in libraries: fad or fact?
}

\author{
J.H. Viljoen* \\ Library Services, University of Stellenbosch, Private Bag 5036, Stellenbosch, 7600 Republic of South Africa \\ jhvi@maties.sun.ac.za \\ P.G. Underwood \\ School of Librarianship, University of Cape Town, Private Bag, Rondebosch, 7700 Republic of South Africa \\ pgu@education.uct.ac.za
}

\begin{abstract}
This article considers the present circumstances in libraries and the changes that are taking place arising from present uncertainty. Some of these changes are brought about by the changing environment, the ever increasing demands of users, the fast growth and influence of information technology as well as certain external factors, for example the declining buying power of the Rand. Libraries as service organizations are very conscious of all these influences. The possible use of Total Quality Management (TQM) and the application of Deming's 14 points model in solving some of these problems are also discussed. From the discussion of the 14 points it is evident that the application and use of TQM is a fact and not a fad in libraries. The importance of the application is focussed on the fact that TQM is helping libraries to establish a culture of never-ending improvement of quality of products and services. By doing this, library management also indicate to funders that they are prepared to make the most of available financial support to meet the demands of users. The article concludes by emphasizing that this process of change and growing user demands must be managed well and that the principles of TQM offer librarians help in this regard.
\end{abstract}

Hierdie artikel beskryf die huidige omstandighede sowel as veranderinge wat in biblioteke plaasvind asook die gepaardgaande onsekerheid. Van hierdie veranderinge spruit voort uit die omgewing waarbinne biblioteke funksioneer, die steeds toenemende gebruikersbehoeftes, die vinnige ontwikkeling en invloed van die informasietegnologie asook sommige eksterne faktore soos die dalende koopkrag van die Rand. Biblioteke is diensorganisasies en dra deeglik kennis van al hierdie faktore. Die artikel bespreek verder die filosofie van Total Quality Management (TQM) gebaseer op die 14 punte van Deming en dui aan hoe dit op biblioteke van toepassing kan wees. Uit hierdie bespreking is dit duidelik dat TQM ' $n$ feit en nie ' $n$ gier is nie. Die belangrikheid van die toepassing TQM vir biblioteke is daarin geleë dat dit 'n kultuur van voortdurende verbetering van die kwaliteit van produkte en dienste teweeg bring. Indien biblioteke sukses hiermee behaal, sal dit ook vir owerhede wat biblioteke finansier ' $n$ aanduiding wees dat fondse goed bestee word en dat aan gebruikersbehoeftes voldoen word. Die artikel sluit af deur te beklemtoon dat die proses van verandering goed bestuur moet word en dat die filosofie van TQM 'n bydrae hiertoe kan lewer.

*Author to whom correspondence should be addressed.

The literature of library and information science contains numerous examples where the techniques and methods of other disciplines have been applied successfully to libraryrelated activities and problems, often with adaptations. The strategic management field, as well as human resources management, are good examples. It is however also true that modern libraries are managed according to principles which are common to the management of any business or organization. The rapid development and ubiquity of information technology has further encouraged the use of a common set of principles. An important reason for this is that the tremendous speed of socio-technical development brings a great degree of uncertainty and managers seek to reduce this by exploring and relying upon common areas of best practice. The effective management of change is the major challenge for a manager in this environment. The needs of users have also changed and rising costs and the need to maintain standards in service delivery have become major issues. Users expect quality services, quality in provision of infrastructure, as well as training.

The provision of high quality services has always been the responsibility of library managers. With a rapidly changing environment, greater competition for resources, the ever- increasing cost of information carriers, the rising expectations of funders and clients and the increasing complexity of information provision from a big variety of providers, it is evident that management skills must match these more intense demands on, and threats to, library and information services.

It is in this regard that the application of Total Quality Management (TQM) could assist library and information managers very well. The ideas encapsulated in TQM, as described by its originator W. Edwards Deming (1986), have had a pervasive influence which has spread far beyond their origins in the Center for Advanced Engineering Study of the Michigan Institute of Technology. This article describes the concept of TQM, discussing Deming's approach and some later modifications, and considers its importance for libraries, with some assessment of its suitability in the library and information service environment.

\section{What is TQM?}

The setting of standards and their use in controlling the quality of production is not a new concept. In manufacturing, the Japanese showed the modern world how the quality of goods could improve and for this improvement to be 
maintained. For a long time people thought that the only way to achieve quality was through a proper system of inspection and application of standards. Better equipment and methods of production led to lower production costs but, in an environment where competition was more intense and user expectations were higher, management had to meet these higher demands and expectations by improving product quality and restructuring existing management practices to reduce waste, defective manufacture, and ineffective procedures. It was believed that this could lead to higher or increased customer satisfaction.

According to Mullen (1993:91) the concept of TQM has received wide notice in the United States in the last decade and public and private organizations alike are adopting this new approach to managing the process of improving themselves. Kruger (1995:16) stated that TQM can be described as a management approach to long-term success through customer satisfaction.

The management literature is abundant with definitions of TQM, although there is no single widely accepted definition. It is, however, true that most management consultants agree about a number of essential components in describing the concept of total quality management: for example, there should be a

- strong focus on the client;

- thorough commitment to quality and continuous improvement, for example in service delivery;

- reliable system of information supply for decision making (management information system);

- proper training system for staff; and

- direct involvement of staff and empowerment throughout the process.

Some other elements that are often included in a description of TQM are:

- the adoption of a very systematic approach to operations;

- long-term thinking;

- linking productivity with quality (Kruger, 1995:17); and

- knowledge about user needs and commitment to meeting those needs, and ultimately, to exceeding user expectations;

- leadership that can create a vision based on the needs of users; and

- confidence in staff, that they can deliver quality service to users (Gapen, Hampton \& Schmitt, 1993:21).

'Total quality management (TQM) ... describes an organizational approach to implementing quality improvement, particularly of products and services' (Henkel, Repp-Bégin \& Vogt, 1993:147).

Cantoni (1993:133) defined TQM as

'a non-hierarchical and non-bureacratic culture, based on an operating philosophy of employee involvement, committed to meeting customer requirements through the continuous improvement of key business processes, as measured by a variety of analytical tools'.

\section{According to O'Neil (1994:x),}

'Total Quality Management (TQM) brings together the best aspects of organizational excellence by driving out fear, offering customer-driven products and services, doing it right the first time by eliminating error, maintaining inventory control without waste, focussing on employee development and empowerment, and more, and completes it with strategic direction and a customer-driven culture'.

The two people associated with the birth of the TQM movement are W. Edwards Deming and J.M. Juan. Some forty years ago Deming, father of the quality revolution, assisted the Japanese to become the world manufacturing leaders they are today. Many service industries, including libraries, have also adopted the Deming thinking. The Deming TQM philosophy is based on 14 points, conveniently outlined by Mackey and Mackey (1992:57-61).

The 14 points and the application of TQM are very relevant to a consideration of service delivery in South African libraries:

- Restructuring is taking place in a great number of libraries. This is due to the fact that the new dispensation is seeking to ensure access to all services by all inhabitants of the country. Development is so essential as part of the process and, if reconstruction and development initiatives are to succeed, the process must be carried out in a logical manner and with an acceptable basis. The Deming approach offers such a basis. Fitch, Thomason and Wells (1993) discuss the centrality of TQM as a consideration when restructuring.

- User expectations of the ability of a library or information service to deliver high quality services are growing. The importance of information as a resource (and, even, a product) is being more broadly recognized by government, organizations and other social structures.

- Linked to the user demand for services is the influence of information technology. Students, for example, are becoming more computer literate and the academic library environment has changed substantially in the increased range of technology which can be used as channels for its service delivery. The subject librarian has become more of a consultant in information services and many users want to conduct some, at least, of their searches from their own workstations.

- If users want to be more independent in their search for information, training in the use of information systems and databases is very important. This is also true for the staff working in these environments where change is taking place so fast. By training users and staff, both can be empowered to do more and in the process achieve better results for the organization as a whole and for the satisfaction of their own aspirations

- The cost of library services is going up tremendously. Some of the reasons for this are:

1. large price increases for library materials, especially periodical subscriptions; 
2. the declining buying power of the Rand: in 1978 one

Rand could buy $\$ 1.78$; by 1996 the Rand had declined in value to 22 U.S. cents

3. 14\% Value Added Tax levied on all imported library materials, and other information resources.

If funders are not assured of proper management of scarce resources as well as quality services to users, they will question the utility of continuing to support investment in libraries.

The central core of the Deming philosophy is one of continuous improvement in service delivery associated with meeting and exceeding the expectations of users: both are of critical importance to the management of a modern, responsive library and information service.

Juran, another of the progenitors of TQM, has underlined the signal importance of the managerial role in developing a culture of quality. Juran developed the notion of fitness for use or purpose and carefully distinguished it from a simple regime of conformance to standards or specifications (Riggs, 1994:91).

\section{Deming approach to TQM}

Point 1: Create constancy of purpose for improvement of product and service

Problems can be categorized in two ways: problems of today and those of tomorrow. A library manager may become preoccupied with everyday, apparently urgent, problems and lose sight of the long-term perspective: the result will be a management style characterized by incomplete planning, often-precipitate action and reliance on precedent rather than thought. A mission statement must contain a short 'statement of purpose' which should be a guiding principle against which a manager assesses urgency and a need for continual, personal involvement in respect of every item or point of decision. The concept of the mission statement is to act as a focus for deciding what is critical to the work of the organization and where best within the organization each such issue should be considered and resolved. Using a mission statement in this way will mean that a conscious decision for the organization not to be involved in some activities will be taken and that all managers will have to consider to which issues they can best contribute. The culture of the mission statement is that it is understood, shared and accepted by all those associated with the organization and that all employees work towards its achievement. However, such cultures cannot be forced upon others and require constant reinforcement and evidence of commitment by senior management. Kruger (1995:93) notes a pervasive problem: that there are so many tools for management that people have become wary of new ideas, thinking it is just a passing phase. It will need time for management to understand the quality philosophy and setting a good example through consistency of purpose. The mission statement is, thus, a central component of the Deming TQM approach.

\section{Point 2: Adopt the new philosophy}

A paradigm shift in the thinking of library management and staff is needed if such a challenging philosophy is to be adopted successfully. Quality must become the primary concern of everyone in the library but this requirement must move beyond simple avowal towards a complete change in perspective on how to measure quality. The essence of the new philosophy is to change from the measuring of results to the measuring of the process by which the results are achieved. For example, if a subject librarian indicates that 250 extra searches were carried out during a certain period, the question should be whether the searches were done better. Were the users more satisfied? The increase of 250 is not, of itself, sufficient: rather, the quality in the process as evidenced by higher user satisfaction is the key consideration. To achieve this, there must be a consistent and sustained redirection of effort towards continual improvement to systems, procedures, services and products.

\section{Point 3: Cease dependence on mass inspection to achieve quality}

Deming was of the opinion that quality does not come from inspection, but from improvement of the process. Mass inspection is a result-oriented attitude and not conducive to producing quality. In the past the attitude was to eradicate poor products or services by inspection: in other words, the quality control was external and focussed on the product; with the new quality paradigm, the objective is to build good quality into the product or service. This philosophy encourages quality assessment at every step of the process and makes it a natural, internal, part of the production process. When errors occur, the task for management is to find out where and why they have occurred and then adjust the process, not reprimand the staff. Both Deming and Juran are of the opinion that the vast majority of problems with quality can be traced to faulty or ineffective processes rather than being the fault of staff (Riggs, 1994:91).

An important aspect of this process is to listen to staff, their description of the problems they have encountered and their proposals. Staff normally take pride in their work and will do quality work if they are given the opportunity. By listening carefully, library management can create an environment where quality work is possible. The ability to listen is a key managerial skill but one which needs practice and conscious effort (Underwood, 1996:139).

Point 4: End the practice of awarding business on the basis of price tag; instead minimize total cost

Library budgets in South Africa are presently under severe pressure for a number of reasons, discussed earlier. In making decisions to spend money, a sense of crisis can persuade managers that the long-term benefits of quality (for example, durability, trust in the supplier and trouble-free service) can be traded for the short-term benefit of lower per-unit price. An example is the selection of a CD-ROM product: the 
subject librarian could select a cheaper product from a not so well-known vendor and sacrifice trust and quality service, but in the long run it may be so unreliable as to be a source of irritation to the users. Price should, therefore, never be the only consideration and a conscious decision to accept a low price must take into account the possible need to spend money later on overcoming any latent deficiencies.

\section{Point 5: Improve constantly and forever the system of production and service}

We live in a time where change is almost the only constant factor - the speed with which changes takes place in the uses and tools of information technology and in service requirements of users, has become difficult for service providers to anticipate. The question for any manager of a library or information service must be: how has the library environment changed to meet these new challenges? The personal question which any information worker must ask is: how have I improved to meet this change? Collectively, the question must be: how have our services, in all regards, changed to meet new demands and ways of working? If changes are not aimed at improving quality, they do not represent an improvement for the users.

\section{Point 6: Develop training for all employees}

Change brings uncertainty and, if management wishes to reduce the debilitating effects of the attendant anxiety which may follow in the absence of strategic management (Underwood, 1996:88), and institute quality in the workplace, a formal, well-developed, training program is essential. Training is applicable to all levels of staff in a library or information service, from management to library assistants and other information workers. Part of the training process should be for trainees to gain some idea of the responsibilities of members of staff in other parts of the organization and how these link and intersect with their own. Subject librarians should, for instance, also be knowledgeable about the work of the acquisitions department and its distinctive role. A key part of this knowledge is an understanding of how a quality failure in one department may have a major impact upon the work of another.

Training programs should be well planned and quality built-in at each step in the training process. Feedback, such as statistical, reports and interviews, is important to support the process, to eliminate problems and to improve the quality of training.

\section{Point 7: Adopt and institute leadership}

A leader understands the effect of the procedures in an organization, without necessarily being an expert in their separate use. If this knowledge of the impact of procedures is applied to the processes involved in a library or information service, quality could be added at every step where a particular procedure is involved. Knowledge of impact also assists managers to nurture staff to become the very best at their jobs: it is this which builds quality information services. If there is doubt about the effectiveness of a service, the leader must start an investigation, using applicable techniques to put a better service in place. For example, a feeling that there is a need for an improved mail service might lead a manager to assess the effect of an unreliable service on the mission of the organization and then consider ways in which quality enhancements, such as speedier delivery of mail and reduction in incorrect delivery, could be instituted. This notion of impact assessment can be applied to many situations and is a critical element in the culture of continuous improvement.

\section{Point 8: Drive out fear}

Fear is a negative feeling and in the workplace it is destructive, both to individuals and institutions. Such a negative feeling may lead to absenteeism, withdrawal, low quality work and even physical illness arising from stress and inner conflict. Fearful employees will not be prepared to take the risk of suggesting or exploring improvements because they will wish to avoid anger, blame and other negative comments Opportunities to improve production and quality may be quite apparent to them but they will not be prepared to volunteer this information. According to the Deming philosophy of TQM, it is the responsibility of management to assist with eliminating such fear from the workplace, replacing it with a context in which people are encouraged to bring forward observations and ideas which can then be discussed, evaluated and, if found suitable, adopted.

With the implementation and use of sophisticated systems and information technology many people fear their use or are apprehensive of criticizing and making suggestions about the use of such complex systems. In this regard management has a strong leadership role in seeking to allay fear of the consequences of making suggestions by means such as instituting proper training programs during which there can be discussion of what constitutes an effective system from the point-of-view of staff and users and some attempt at assessing to what extent the new system meets such criteria. It is important for all to recognize that a tool is only effective if it helps people to achieve a particular task well: however elegant the design, if the job does not need doing or if the finished product is poor, the tool needs to be improved. The people using the tool have an important contribution to make towards creating a more effective design.

\section{Point 9: Break down barriers between staff areas}

There are two kinds of barriers: internal barriers and external barriers. Internal barriers refer to the organizational structure and are a product of bureaucratization. Barriers exist mostly between departments: for example, departments of information services and technical services work with identical material (items of stock) but have different 'views' of such items. Technical services may be concerned with retaining an item until it has been correctly processed and will lay 
emphasis on the quality of the bibliographic record arising from the item as a bibliographic unit; an information service department may be concerned with the informational content, as distinct from the item as a 'unit', and the quality consideration will be exemplified through attempts at reducing delays in providing salient information to the user.

Some of the reasons for these organizational barriers are:

- lack of communication

- competition

- lack of constancy of purpose

- lack of understanding of the role of each service area in relation to the mission of the library

- jealousies and personal grudges.

The biggest problem of internal barriers arises from a lack of a uniform view of the mission of the library or information service. One result is that each area, or department, develops its own sense of mission which may make sense in terms of what the staff of that department or area consider their role to be but does not articulate with that of other areas or departments. Working at cross-purposes with one another, creates competition and may have detrimental effects on the overall production and quality of service of the library.

External barriers may exist between the library and its users. For example, users expect the library to remain open until very late at evening, but insufficient staff may make this expectation impossible to satisfy or so expensive that users are unwilling to provide the necessary additional funding. Clearly, the parent organization for a library (the commercial firm that owns a special library, a municipality responsible for the public library service or a tertiary education institution providing a library and study space) may also create barriers by limiting the capacity of the library staff to respond to user needs, even if those staff consider that the request from users is valid and wish to respond positively.

There could also be external barriers between the library and some vendors. Some of the reasons that are valid for internal barriers, are applicable here:

- lack of communication; and

- insufficient understanding of the role of the library.

The critical difference between internal and external barriers is that the former are more immediately susceptible to scrutiny, questioning and elimination. This is not to suggest that the organization of staff into a divisionalized structure should be abandoned: a barrier exists because divisionalization allows, and sometimes fosters, an inward-looking attitude to objectives and tasks, where the focus is within the department rather than on the overall health of the organization and its users. Internal barriers are not, however, an inevitable consequence of such organizational structuring. External barriers are more difficult to eliminate or reduce because the participants in barrier-building, the staff and those outside the organization, are not necessarily going to share the same views of the organization and may not easily be brought together into a suitable forum within which a mutually-agreed view could be developed.
It is important to realize that these barriers exist, but it is also important to understand that these barriers could be eliminated or their deleterious effects mitigated. How could this be done? The starting-point for dealing with both types of barrier must be by promoting the mission statement of the library: use models and organizational charts, work teams and discussion groups. Everyone in the organization must be willing to substitute teamwork for personal territory. In a total quality environment employees understand the importance of all the service areas of the organization, have frequent meetings attended by everyone in the organization and work together to analyse and study the process of the organization (Mackey \& Mackey, 1992:61).

\section{Point 10: Eliminate slogans, exhibitions and targets for the workforce}

There is a place for such motivational focusses in every library, but they must be used with discretion or their effect can be damaging to morale. For example, in a time of downsizing, there may be no point in having posters and slogans promoting longer hours of service unless the staff reduction or redeployment has been biased in favour of protecting user services. The purpose of posters and slogans is to create enthusiasm, but unfortunately they do nothing to improve faulty processes. Targets, if not carefully considered and balanced by an understanding of the concomitant need for quality, may lead to a simple-minded concern with quantity and an overall poorer service. Targets also encourage competitive attitudes which may serve to heighten the internal barriers considered in the previous section.

Point 11: Eliminate numerical quotas for the workforce and eliminate numerical goals for people in management

Many librarians take pride in the statistics that they keep; annual reports reflect these in a number of presentations: graphs, bar charts, etc. Unfortunately statistics such as

- how many books were issued, and

- reference questions were answered,

- number of users registered, or

- how many retrospective conversions were added,

do not reflect anything other than numbers. They are just simple statements of a short-term position and, unless related to trends in growth or decline, provide no guidance for understanding the essential character and quality of a service. Statistics are normally used to measure the process by which ends are achieved and not the end results. This is a critical distinction. If a process is the subject of regular statistical analysis, this can provide vital insight but a quality end product can only be achieved if purpose and effect of use of the product are taken into consideration. 


\section{Point 12: Remove barriers that rob people of pride in their work}

From the human resources management perspective, it is essential to establish an infrastructure for staff where they can work and contribute to quality services. How can this be done? Staff members should have a clear job description, which provides them with the information that they need to understand what is required of them. The mission statement of the library, medium-term objectives and short-term goals provide a framework for interpreting the job description and understanding the unique and vital contribution every staff member makes to overall success. By discussion of the meaning of such statements, staff can be empowered to carry out their tasks to achieve these goals and objectives and entrusted with responsibility for the quality of their own work. If a system of performance evaluation is in operation, it should not be perceived as an annual threat or as a mutual waste of time. It is essential that the culture of the organization supports the view that it is to be used as a means of feedback and communication regarding staff performance between all participants. Peer-to-peer feedback is often neglected in performance evaluation: if there is an over-concentration on superordinate-to-subordinate evaluation there will be an intensification of the divisional barriers alluded to in an earlier section. A judgement about performance should be informed by collective views and feedback, out of which grows a better understanding of role, commitment to objectives and confidence that communication between the appraiser and appraisee has been successful.

As with all aspects of management, it is critically important to be sure that performance evaluation is achieving positive results in an effective manner. If it is not contributing to better production and quality, it is a barrier and its form should be reconsidered. It is, in any case, worth considering complementary approaches such as the use of quality circles (Hanks \& Wade, 1994:44-50). This is a peer-group process, whereby a small group of staff with responsibility for common areas of service, or with work experience in common, volunteer to meet regularly to identify problem areas or opportunities and consider ways of improving services. It is within such circles that peer-to-peer evaluation can occur spontaneously or as a planned part of the work of the circle. Because considerations of authority and hierarchical control are largely absent from such discussions any negative feedback to an individual can be less threatening and more concerned with identifying how to assist than with allocation of blame. Nevertheless, such approaches will only work within a supportive culture and need careful management if they are to be effective (Speakman, 1994:52).

Point 13: Encourage education and self improvement for everyone

To combat fear and uncertainty in a fast moving and everchanging work environment, education, training and retraining of staff are imperative. Add to this the adoption of
Deming's TQM philosophy and it becomes essential to train staff so that they understand the meaning and impact of the 14 points. Without proper training and education, staff cannot be expected to do their jobs properly or to be motivated to improve. If a program of continuing education is followed with the clear aim of enskilling and explaining roles, staff are more likely to take pride in their work and to assume a greater degree of responsibility for the quality of their work.

\section{Point 14: Take action to accomplish the transformation}

It is the responsibility of library management to set the example in the process of transformation: leadership and a firm espousal of the principles of TQM are essential. Quality will come when individuals in the library understand and adopt the philosophy of never ending improvement. If library management takes the lead and sets the example, the longterm commitment to quality in all library processes is likely to follow. This commitment needs to be understood as applying to all aspects of service provision, from answering the phone to handling difficult reference questions (Mackey \& Mackey, 1992:61). If staff are serious about providing better and improved services to customers, the use of TQM in this regard is fundamental but it will only work if this belief is also espoused by management at all levels. It is especially important that senior managers recognize that TQM cannot be grafted onto a command-driven authority structure in which the flow of communication is, essentially, downwards. A dictatorial approach to management and a TQM approach are inimical.

\section{Importance of TQM for libraries: fad or fact?}

Libraries and information services are intrinsically complex to manage because of the wide range of user expectations and demands placed upon them. Demands are increasing and resources, in all respects, are limited. As service-oriented organizations, libraries are striving to give the best to their users; quality service must be the departure point. If this is true, then libraries are a natural entity for the application of TQM. Most libraries are pursuing excellence in their services as well as products and, if the objective is to maintain this, TQM could assist in the pursuit of never ending improvement. TQM could be the catalyst that causes librarians to examine issues such as leadership, staff empowerment, incentive programs, work simplification, innovation, and performance evaluation (Dougherty, 1992:3).

Library users can only describe quality by the characteristics of the service or product they encounter. From the perspective of the user, the criteria for judging satisfaction with a service can be reduced to four elements:

- a service is available at the moment it is needed, or

- the information supplied is exactly correct

- the service is of a high quality, and it is delivered by

- professional, well trained staff. 
'Quality is what one needs and wants, not what you think is needed or what is convenient for you to deliver' (Riggs, 1992:481).

The importance of TQM for libraries is not only centred around the user's needs but also in anticipating and exceeding the demands of the fast changing environment of service delivery in libraries. Most libraries today operate according to a strategic plan containing vision and mission statements, goals and objectives and short-, medium- and long-term plans. To make this all effective, TQM requires that the management of the library commit itself to the process and actually set the example in displaying a commitment to continuous quality improvement. The quest for quality must be given meaning through actions. Implementing TQM as part of the future plans of a library consists in not only changing certain procedures, but a total rethink of all its operations, where the culture is quality-driven, customeroriented and marked by teamwork and quality service to the users.

\section{Conclusion}

In any service industry, users are of central importance and if their demands are not met, there is a failure in reaching the objectives of that industry. Present circumstances in the library environment of change and uncertainty, growing demands, the influence of information technology and reconstruction and development, makes it essential that this process be arranged on a rational and principled basis. The application of the philosophy of TQM offers a formal and systematic approach to these problems and could result in a process where continuous improvement of services is the final result. Although there is evidence that this is true, TQM is not a quick solution: it could take up to three years to reap the benefits of a properly implemented TQM program. TQM could, however, lead to an alternative way of doing things and enable libraries to be more flexible and responsive; to act more proactively, instead of reactively, in an environment where the only certainty seems to be that of constant change.

\section{References}

CANTONI, C.J. 1993. Corporate dandelions. New York: Amacom.

DEMING, W.E. 1986. Out of the crisis. Cambridge, MA: MIT Center for Advanced Engineering Study.

DOUGHERTY, R.M. 1992. Editorial: TQM - is it the real thing? Journal of academic librarianship, 18(1):3.

FITCH, D.K., THOMASON, J., \& WELLS, E.C. 1993. Turning the library upside down: reorganization using Total Quality Management principles. Journal of academic librarianship, 19 (5):294-299.

GAPEN, D.K., HAMPTON, Q. \& SCHMITT, S. 1993. TQM: the directors perspective. Journal of library administration, 18(1/ 2):15-28.

HANKS, N. \& WADE, S. 1994. Quality circles: realistic alternatives for libraries. In O'Neil, R. ed. Total Quality Management in libraries: a sourcebook. Englewood: Libraries Unlimited:44-50.

HENKEL, A.G., REPP-BEGIN, C. \& VOGT, J.F. 1993. The 1993 Annual: developing human resources. San Diego: University Associates.

KRUGER, Y. 1995. A literature study on total quality, with special reference to service quality, and its application to libraries. (MBibl thesis). Stellenbosch: University of Stellenbosch. (Unpublished).

MACKEY, T \& MACKEY, K. 1992. Think quality! The Deming approach does work in libraries. Library journal, 117(9):57-61.

MULLEN, J.A. 1993. Total Quality Management: a mindset and method to stimulate change. Journal of library administration, 18(3/4):91-108.

O’NEIL, R. 1994. Total Quality Management in libraries; a sourcebook. Englewood: Libraries Unlimited.

RIGGS, D.E. 1992. TQM: quality improvement in new clothes. College and research libraries, 53(6):481-482.

RIGGS, D.E. 1994. Strategic quality management in libraries. In O'Neil, R. ed. Total Quality Management in libraries: a sourcebook. Englewood: Libraries Unlimited:88-99.

SPEAKMAN, G. 1994. Why not consider quality circles? In O'Neil, R. ed. Total Quality Management in libraries: a sourcebook. Englewood: Libraries Unlimited:51-59.

UNDERWOOD, P.G. 1996. Soft systems analysis and the management of libraries, information services and resource centres. London: Library Association. 